\title{
PERAN FISIOLOGIS SARI KEDELAI HITAM DIPERKAYA MIKROENKAPSULAN MINYAK SAWIT MENTAH PADA PENDERITA DIABETES MELITUS TIPE-2
}

\author{
[Physiological Roles of Black Soybean Milk Enriched with Microencapsulated \\ Crude Palm Oil in Diabetes Type-2 Patients]
}

\author{
Reno Irwanto ${ }^{1) \star}$, Dede Robiatul Adawiyah" ${ }^{2)}$, dan Fransiska Rungkat Zakaria ${ }^{2)}$ \\ 1) Program Studi IImu Pangan, Sekolah Pasca Sarjana, Institut Pertanian Bogor, Bogor \\ 2) Departemen IImu dan Teknologi Pangan, Fakultas Teknologi Pertanian, Institut Pertanian Bogor, Bogor \\ Diterima 05 April 2016 / Disetujui 30 Mei 2016
}

\begin{abstract}
Diabetes mellitus type-2 (DM-2) is a disease characterized by high level of blood glucose which may result in complications of other diseases. Currently, the disease prevalence of DM-2 has been increasing. Appropriate diet patterns can be a solution for DM-2 control. Black soybean milk (BSM) enriched with microencapsulated crude palm oil (CPO) is an example. The objective of the study was to determine the effectiveness of BSM containing microencapsulated CPO in controlling and improving the condition of DM2 patients. The intervention consist 2 group with 15 people DM-2 was given BSM $240 \mathrm{~mL}$ containing $0.4 \mathrm{~g}$ microencapsulated CPO daily for 28 days, while a control group with 11 people DM-2 without intervention product. Data were analyzed using software SPSS 15.0 with student-t test at significant level $\alpha=5 \%$. Medicines prescribed to all volunteer were not terminated during the intervention period. The microencapsulated CPO usedin this study has a moisture content of $1.77 \pm 0.15 \%$, solubility value of $65.39 \pm 2.71 \%$, and total carotene of $295.24 \pm 7.40 \mathrm{ppm}$ while BSM has protein content of $2.76 \pm 0.13 \%$, fat $1.17 \pm 0.06 \%$, ash $0.12 \pm 0.08 \%$, moisture $94.69 \pm 0.04 \%$, and carbohydrate (by difference) $1.27 \pm 0.10 \%$. The consumption of BSM containing microencapsulated CPO showed insignificant effects on Fasting Blood Glucose (FBG) levels $(P>0.05)$, but significantly reduced cyclooxygenase 2 levels $(P<0.05)$ and MDA levels $(P<0.05)$. The control group showed insignificant differences for $F B G(P>0.05)$, cyclooxygenase 2 $(P<0.05)$, and MDA level $(P>0.05)$. The significant changes indicated that BSM containing microencapsulated CPO has against DM-2 disease.
\end{abstract}

Keywords: black soybean milk, diabetes mellitus type-2, microencapsulated MSMn

\begin{abstract}
ABSTRAK
Diabetes melitus tipe-2 (DM-2) ialah kondisi kadar glukosa dalam darah yang tinggi dan akan berimplikasi pada komplikasi timbulnya penyakit lain. Saat ini, angka prevalensi penderita DM-2 semakin meningkat. Pola diet yang tepat dapat menjadi solusi terapi DM-2; salah satunya adalah minuman sari kedelai hitam (SKH) yang diperkaya mikroenkapsulan minyak sawit mentah (MSMn). Tujuan penelitian adalah mengetahui peran fungsional SKH yang diperkaya mikroenkapsulan MSMn dalam mengontrol dan memperbaiki kondisi penyakit DM-2. Penelitian ini dilakukan selama 28 hari dengan partisipasi 15 relawan yang diberi SKH sebanyak $240 \mathrm{~mL}+0,4 \mathrm{~g}$ mikroenkapsulan MSMn sebagai grup perlakuan dan 11 relawan sebagai grup kontrol tanpa diberikan apapun. Data dianalisis menggunakan software SPSS 15.0 dengan uji $t$-student pada taraf nyata $\alpha=5 \%$. Obat-obatan yang digunakan oleh semua relawan tidak berubah selama periode intervensi. Produk yang diintervensi berupa mikroenkapsulan MSMn memiliki kadar air 1,77 $\pm 0,15 \%$, kelarutan $65,39 \pm 2,71 \%$ dan total karoten $295,24 \pm 7,40$ ppm sedangkan SKH

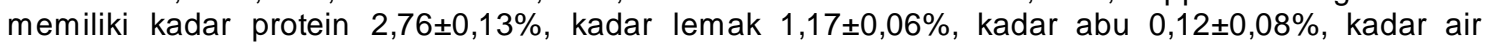
$94,69 \pm 0,04 \%$ dan kadar karbohidrat by difference $1,27 \pm 0,10 \%$. Konsumsi SKH yang mengandung mikroenkapsulan MSMn tidak memberi pengaruh terhadap kadar GDP $(P>0,05)$ tetapi menurunkan secara nyata kadar siklooksigenase $2(P<0,05)$ dan MDA $(P<0,05)$. Relawan grup kontrol menunjukkan hasil yang tidak signifikan (taraf $5 \%$ ) untuk penurunan GDP $(P>0,05)$ dan peningkatan kadar MDA $(P>0,05)$, namun memberikan pengaruh signifikan terhadap penurunan siklooksigenase $2(P<0,05)$. Perubahan nilai parameter uji yang teramati menunjukkan bahwa minuman SKH yang mengandung mikroenkapsulan MSMn memiliki peran funsional terhadap penyakit DM tipe-2.
\end{abstract}

Kata kunci: diabetes melitus tipe-2, mikroenkapsulan MSMn, sari kedelai hitam

\footnotetext{
*Penulis Korespondensi:
}

E-mail: ireno@outlook.com 


\section{PENDAHULUAN}

Diabetes melitus (DM) merupakan penyakit kronis yang terjadi akibat tubuh tidak dapat menghasilkan hormon insulin dalam jumlah yang cukup atau tidak dapat memanfaatkan insulin yang ada dalam tubuh dengan baik. Salah satu jenis DM adalah DM tipe-2 (DM-2). DM-2 terjadi karena tubuh tidak mampu merespon insulin walaupun tubuh dapat menghasilkan insulin; yang lebih dikenal dengan kondisi insulin resisten. Penderita DM-2 pada umumnya memiliki tingkat stres oksidatif yang tinggi didalam tubuhnya sehingga berdampak pada kerusakan atau komplikasi penyakit lainnya (IDF, 2013). Indikator yang paling umum bagi penderita DM adalah dengan mengukur tingkat kadar glukosa darah, enzim siklooksigenase (COX-2), dan molanaldehida karena berhubungan dengan tingkat komplikasi dan keparahan penyakit DM-2. Semakin tinggi jumlah radikal bebas di dalam tubuh, maka semakin besar kemungkinan terjadi inflamasi, yang diukur melalui penentuan kadar COX-2. Demikian pula dasar pemikiran pengukuran kadar senyawa malonaldehida yang bersifat toksik yang terbentuk dalam tubuh penderita DM-2. Tingkat stres oksidatif dapat dikontrol dengan mengonsumsi makanan yang memiliki nilai indek glikemik (IG) rendah serta mengandung senyawa antioksidan, komponen bioaktif, dan serat pangan (Biglari et al., 2008).

Kedelai hitam merupakan salah satu bahan pangan yang dapat berperan penting dalam menurunkan tingkat keparahan DM-2. Sejumlah penelitian telah mengungkapkan kelebihan kedelai hitam yaitu dari kulitnya yang mengandung antosianin dan tidak dimiliki oleh kedelai kuning pada umumnya. Selain itu kandungan biji kedelai hitam sendiri memiliki senyawa fitokimianya seperti antosianin, isoflavon, dan saponin ( $\mathrm{Kim}$ et al., 2006; Slavin et al., 2013). Hasil penelitian Powell et al. (2002), menyatakan nilai IG sari kedelai adalah 31, termasuk dalam kategori bahan pangan dengan nilai IG rendah sehingga baik untuk penderita DM-2. Hal tersebut menjadikan minuman sari kedelai hitam dengan kandungan IG yang rendah, senyawa bioaktif, dan serat pangan sebagai minuman yang dapat menurunkan risiko DM-2. Selain kedelai hitam, minyak sawit mentah (MSMn) diketahui kaya akan sumber antioksidan; yaitu karotenoid, tookferol, tokotrienol, fitosterol, senyawa fenolik, dan senyawa fitonutrien lainnya yang baik bagi tubuh (Boateng dan Lee, 2013). Karotenoid merupakan pigmen yang mudah teroksidasi (Chen et al., 2014). Selain itu, flavor MSMn murni memberikan palatabilitas dan tingkat penerimaan sensoris rendah. Salah satu usaha penanganan hal tersebut adalah dengan teknik mikroenkapsulasi (Dubey et al., 2009). Penelitian mikroenkapsulasi MSMn dengan berbagai metode pengeringan, meliputi spray, drum, dan tray drying yang telah dilakukan oleh Wulandari et al. (2014) menunjukkan total karoten tertinggi dihasilkan dari metode tray drying, yaitu $230 \mathrm{ppm}$. Urutan berikutnya diikuti oleh metode spray drying (160 ppm), dan total karoten paling rendah diperoleh dari metode drum drying (sekitar 78 ppm). Namun, metode spray drying menghasilkan mikroenkapsulan yang lebih homogen dan tingkat kelarutan yang lebih baik dibandingkan metode lainnya. Dengan demikian, penelitian ini menerapkan metode spray drying dalam pembuatan mikroenkapsulan MSMn. Diharapkan minuman SKH yang diperkaya mikroenkapsulan MSMn mampu menurunkan risiko keparahan dan mengontrol penyakit DM-2. Tujuan penelitian ini adalah mempelajari peran fungsional SKH yang mengandung mikroenkapsulan MSMn dalam menurunkan kadar glukosa darah puasa, kadar enzim siklooksigenase, dan kadar malonaldehida pada pasien DM-2.

\section{BAHAN DAN METODE}

\section{Bahan}

Bahan yang digunakan dalam penelitian ini adalah kedelai hitam varietas Cikuray yang didapatkan dari petani binaan Institut Pertanian Bogor di Palembang dan MSMn dari PT SMART.

\section{Pembuatan SKH}

Pembuatan SKH diawali dengan persiapan kedelai hitam yang telah disortasi. Kedelai hitam direndam air mentah selama 12 jam dengan perbandingan kedelai hitam : air sebesar 1:3 (bk/v). Kemudian kedelai hitam dicuci lalu ditiriskan dan digiling bersama kulitnya dengan penambahan air panas bersuhu $80^{\circ} \mathrm{C}$ pada rasio $1: 8(\mathrm{bk} / \mathrm{v})$. Selanjutnya dilakukan penyaringan dengan kain saring 80 mesh dan hasil tersebut dipindahkan ke alat pasteurisasi (Sankyo, Japan) pada suhu $85^{\circ} \mathrm{C}$ selama 15 menit hingga didapatkan SKH. Pengujian proksimat dilakukan SKH berdasarkan metode AOAC, 2005.

\section{Pembuatan mikroenkapsulan MSMn}

Pencampuran maltodektrin dan isolat protein kedelai sebelum air hangat $\left(50-60^{\circ} \mathrm{C}\right)$ ditambahkan. Setelah itu campuran dihomogenisasi dengan homogenizer (Armfield L4R, Inggris) pada kecepatan 1.100 rpm selama 1 menit lalu MSMn dimasukkan dan dihomogenisasi kembali pada kecepatan $1.200 \mathrm{rpm}$ selama 3 menit hingga didapatkan emulsi MSMn. Langkah berikutnya yaitu pembuatan mikroenkapsulan menggunakan alat spray dryer (Buchi 190 , Switzerland) pada suhu inlet $180^{\circ} \mathrm{C}$ dan outlet $80^{\circ} \mathrm{C}$. Kadar air, kelarutan, dan total karoten dari mikroenkapsulan ditentukan. 


\section{Pemilihan relawan dan intervensi produk}

Tahap ini meliputi penyusunan kuisioner dan kriteria inklusi ataupun eklusi untuk menentukan status dan kondisi relawan DM-2. Kriteria inklusi yang digunakan antara lain penderita DM-2 dengan kadar glukosa darah puasa kapiler $>110 \mathrm{mg} / \mathrm{dL}$ (ADA, 2010), usia relawan 25-70 tahun, tidak menderita gangren dan penyakit kronis (berdasarkan hasil pemeriksaan), tidak sedang hamil, bersedia mengonsumsi produk selama masa intervensi (28 hari), bersedia ikut serta dalam penelitian dengan menandatangani lembar informed consent. Kriteria eklusi adalah bukan penderita DM-2, usia diluar batas yang ditetapkan, mengalami gangren dan penyakit kronis, sedang hamil, tidak bersedia mengonsumsi produk, dan tidak bersedia ikut penelitian dengan tidak menanda tangani informed consent. Selanjutnya pengurusan ethical clearance hingga didapatkan persetujuan dengan No: 576/III/ LPPM-PM. 10.05/07/2014 dari Universitas Atmajaya Jakarta Setelah memperoleh persetujuan ethical clearance, maka survei relawan dapat dilaksanakan. Penentuan jumlah relawan minimal dilakukan dengan menggunakan minimum sample size for estimating difference mean between groups (Lameshow et al., 1997). Relawan yang diperoleh pada tahap awal seleksi berdasarkan data pasien DM-2 dari Klinik dr. Katili Darmaga, Bogor sebanyak 34 orang dibagi dalam 2 kelompok, yaitu kelompok perlakuan dan kelompok kontrol. Semua relawan yang terpilih mendapatkan sosialisasi pengetahuan mengenai program, produk, informasi terkait diabetes, pola makan hidup sehat. Relawan diminta untuk menandatangani Informed Consent serta dilakukan pengecekan kadar glukosa darah awal, penimbangan berat badan, pengukuran tekanan darah, dan pengambilan darah. Intervensi relawan dilaksanakan selama 28 hari. Selama proses intervensi berlangsung total jumlah relawan yang tersisa adalah 26 orang, 15 orang pada kelompok perlakuan dan 11 orang pada kelompok kontrol. Kelompok perlakuan diintervensi dengan $240 \mathrm{~mL}$ minuman SKH yang mengandung $0,4 \mathrm{~g}$ mikroenkapsulan MSMn, sedangkan grup kontrol tidak mendapatkan produk intervensi. Relawan tetap menggunakan obat-obatan yang sedang dijalani dan juga dilakukan food recall untuk mengetahui konsumsi makanan relawan selama masa intervensi produk berlangsung (28 hari). Produk segar diantar setiap hari ke rumah relawan sambil memastikan relawan mengonsumsinya.

\section{Analisis karotenoid}

Total karotenoid dihitung dengan menggunakan metode PORIM (2005), sebanyak 0,1 g mikroenkapsulan MSMn dilarutkan dalam heksana dan volume akhir dibuat $25 \mathrm{~mL}$ menggunakan labu takar hingga tanda tera, lalu dihomogenkan. Absorbansi sampel diukur menggunakan spektrofotometer UVVis (Spectrophotometer U-2900 Hitachi, Japan) pada panjang gelombang $446 \mathrm{~nm}$. Pengenceran dilakukan apabila absorbansi yang diperoleh nilainya lebih dari 0-700 dan digunakan metanol sebagai blanko.

\section{Uji kelarutan dalam air (AOAC, 2005)}

Kelarutan MSMn ditentukan dengan menggunakan metode AOAC (2005), kelarutan diketahui dengan membandingkan berat kertas saring akhir dengan berat kertas saring awal dan berat sampel. Sebanyak $1 \mathrm{~g}$ mikroenkapsulan MSMn (a) dilarutkan dalam $20 \mathrm{~mL}$ akuades kemudian disaring dengan kertas saring Whatman No. 42. Sebelum digunakan, kertas saring dikeringkan dalam oven (Memmert, Jerman) pada suhu $105^{\circ} \mathrm{C}$ selama 30 menit dan ditimbang (b). Setelah penyaringan, kertas saring dikeringkan kembali dalam oven selama 1 jam pada suhu $105^{\circ} \mathrm{C}$. Setelah itu, kertas saring didinginkan di dalam desikator kemudian ditimbang sampai tercapai bobot tetap (c).

$$
\text { Kelarutan dalam air }(\%)=\left(1-\frac{c-b}{\frac{100-\% \mathrm{ka}}{100} \times \mathrm{a}}\right) \times 100 \%
$$

\section{Analisis kadar glukosa darah puasa (GDP)}

Kadar glukosa darah ditentukan menggunakan alat tes uji glukosa darah (One Touch, USA). Darah diambil dari jari setelah dibersihkan dengan alkohol, lalu dipijat atau diurut perlahan-lahan, kemudian bagian ujung jari ditusuk dengan jarum (lancet). Tetesan darah ditempelkan pada glucometer strip (One Touch, USA). Kadar glukosa darah terukur pada alat setelah 5 detik, dinyatakan dalam $\mathrm{mg} / \mathrm{dL}$. Pengukuran dilakukan setiap minggu dan pada tahap awal seleksi relawan.

\section{Analisis enzim siklooksigenase (COX-2)}

Enzim siklooksigenase dianalisis menurut metode Zakaria et al. (2014), sebanyak $100 \mu \mathrm{L}$ plasma yang telah diencerkan dengan carbonatebicarbonate buffer (Sigma Aldrich, Jerman) dan reagent COX-2 (Genetex, USA) yang telah diencerkan sebelumnya pada proporsi 1:700 lalu dimasukkan ke dalam lempeng mikro 96 sumur (Nunc maxisorp F96) kemudian diinkubasi pada suhu $4^{\circ} \mathrm{C}$ selama 24 jam untuk melepaskan enzim siklooksigenase ini dari ikatannya dalam membran inti. Cairan dalam lempeng mikro kemudian dibuang dan lempeng mikro 96 sumurnya dicuci dengan larutan PBST (Sigma Aldrich, Jerman), yaitu larutan Polybutadiene-styrene (PBS) mengandung 0,05\% tween 20, sebanyak $250 \mu \mathrm{L} /$ sumur, dibiarkan 1 menit dan larutan pencuci dibuang. Pencucian dilakukan sebanyak 3 kali. Selanjutnya ditambahkan $100 \mu \mathrm{L}$ sari skim 5\% pada setiap sumur dan 
diinkubasi pada suhu $37^{\circ} \mathrm{C}$ selama 1 jam. Cairan dalam lempeng mikro kemudian dibuang dan dicuci dengan PBST sebanyak 3 kali. Setelah itu, ke dalam setiap sumur lempeng mikro tambahkan $100 \mu \mathrm{L}$ antibodi primer (antibodi monoklonal anti COX-2 1:500.000) lalu diinkubasi kembali pada suhu $37^{\circ} \mathrm{C}$ selama 1 jam. Cairan dalam lempeng mikro kemudian dibuang dan dicuci dengan PBST sebanyak 3 kali. Sebanyak $100 \mu \mathrm{L}$ (1:6.000) antibodi sekunder [HRP anti kelinci terkonjugasi antibodi poliklonal tikus (Genetex, USA)] kemudian ditambahkan dan diinkubasi pada suhu $37^{\circ} \mathrm{C}$ selama 1 jam. Cairan dalam lempeng mikro kemudian dibuang dan dicuci dengan PBST sebanyak 3 kali. Kemudian ditambahkan $50 \mu \mathrm{L}$ substrat Tetra Methyl Benzidine (TMB) (Sigma Aldrich, Jerman) yang dilakukan di dalam ruang gelap dan diinkubasi pada suhu $37^{\circ} \mathrm{C}$ selama 15 menit. Selanjutnya, ditambahkan $50 \mu \mathrm{L} \mathrm{H}_{2} \mathrm{SO}_{4}$ $0,1 \mathrm{~N}$ (Merck, Jerman) sebagai larutan stop. Waktu inkubasi dimulai setelah penambahan setiap larutan pada sumur terakhir. Intensitas warna yang terbentuk dapat dibaca dengan benchmark microplate reader (Bio rad, US) pada panjang gelombang 450 $\mathrm{nm}$.

\section{Analisis kadar malonaldehida}

Kadar malonaldehida diukur dengan menggunakan metode modifikasi dari Singh et al. (2002), larutan induk $50 \mathrm{nmol} / \mathrm{mL}$ tetraetoxy propane (Sigma Aldrich, Jerman) dibuat menjadi larutan kerja dengan deret konsentrasi sebagai berikut: 0,$0 ; 2,0$; 4,$0 ; 6,0 ; 8,0 ; 10,0 ; 12,0 ; 14,0 ; 16,0 ; 18,0 ;$ dan 20,0 $\mathrm{nmol} / \mathrm{mL}$. Sebanyak $375 \mu \mathrm{L}$ larutan standar atau plasma darah pada masing-masing tabung mikro sentrifus ditambah dengan 1,5 $\mathrm{mL}$ larutan $\mathrm{HCl} 0,25$ $\mathrm{N}$ (Merck, Jerman) yang mengandung 15\% trichloroacetic acid (Merck, Jerman), 0,38\% thiobarbituric acid (Sigma Aldrich, Jerman), dan 0,5\% butylated hydroxytoluene (Sigma Aldrich, Jerman) dan dikocok. Campuran dipanaskan dalam penangas air (Memmert, Jerman) pada suhu $80^{\circ} \mathrm{C}$ selama 1 jam. Setelah dingin, campuran disentrifus pada kecepatan 3.500 rpm selama 10 menit pada suhu $4^{\circ} \mathrm{C}$. Supernatan jernih diambil dan absorbansi sampel diukur menggunakan benchmark mikroplate reader (Bio rad, US) pada panjang gelombang 540 $\mathrm{nm}$. Data absorbansi diplotkan ke kurva standar TEP (Sigma Aldrich, Singapura) untuk menghitung kadar MDA plasma.

\section{Analisis data}

Semua data hasil pengujian yang didapatkan dikumpulkan dan diolah dengan menggunakan analisis statistik berupa aplikasi perangkat lunak SPSS 15.0. Analisis data yang dikerjakan berupa uji t-student independen dan dependent yang sebelumnya dilakukan uji normalitas persebaran data, bila persebaran data tidak normal dilakukan pengujian secara non parametrik dengan uji Mann Whitney $(\alpha=0,05)$.

\section{HASIL DAN PEMBAHASAN}

\section{Hasil analisis mikroenkapsulan MSMn dan SKH}

Sebelum dilakukan intervensi, mikroenkapsulan MSMn dianalisis terlebih dahulu. Mikroenkapsulan MSMn memiliki nilai kadar air $1,77 \pm 0,15 \%$. Nilai ini lebih rendah jika dibandingkan dengan hasil penelitian yang dilaporkan oleh Umesha et al. (2013) dengan menggunakan teknik spray drying, yaitu sebesar 2,1-3,2\%. Ahn et al. (2008) meneliti mikroenkapsulasi campuran ekstrak jeruk dan rosemary menggunakan metode spray drying juga

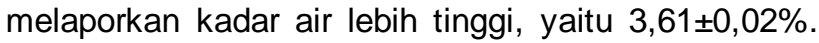
Jika dibandingkan kadar air untuk syarat mutu produk kering seperti sari bubuk (BSN, 1999) dan kopi instan (BSN, 1992) pada nilai 4,0\%, maka nilai yang didapatkan tersebut telah memenuhi syarat mutu produk bubuk kering. Selain kadar air, analisis nilai kelarutan juga dilakukan dan diperoleh nilai $65,39 \pm 2,71 \%$. Analisis total karoten penting dilakukan pada mikroenkapsulan MSMn. Nilai yang didapatkan dari analisis total karoten tersebut adalah 295,24 $\pm 7,40$ ppm. Nilai total karoten yang didapatkan ini lebih tinggi bila dibandingkan dengan hasil yang dilaporkan oleh Rahman (2015), yaitu berkisar 50,71-116,34 ppm. Wulandari et al. (2015) juga melaporkan bahwa pada pembuatan mikroenkapsulan minyak sawit menggunakan metode pengeringan lapis tipis dengan bahan penyalut berupa maltodekstrin, carboxy methyl cellulose (CMC) dan gelatin diperoleh total karoten sebesar 200,16 ppm.

Analisis mikroenkapsulan MSMn dilakukan untuk mengetahui profil mikroenkapsulan yang dihasilkan. Sebelum intervensi SKH terhadap relawan, analisis proksimat SKH dilakukan untuk mengetahui komposisinya dan diperoleh data bahwa kadar proteinnya adalah $2,76 \pm 0,13 \%$, kadar lemak $1,17 \pm$

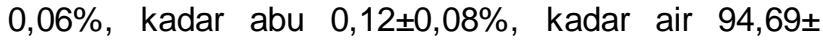

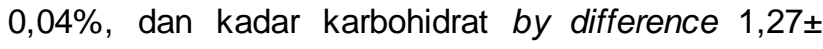
$0,10 \%$. Jika dibandingkan dengan syarat mutu sari kedelai menurut BSN (1995), nilai kadar protein yang ditetapkan adalah 2,00\% dan kadar lemak $1,00 \%$, maka SKH yang dibuat telah melampaui nilai standar SNI sari kedelai.

\section{Kadar gula darah puasa (GDP)}

Intervensi diet minuman SKH yang mengandung mikroenkapsulan MSMn terhadap penderita DM-2 berdasarkan uji $t$-student berpasangan pada taraf nyata $5 \%(P>0,05)$ tidak memberikan pengaruh secara signifikan terhadap kadar GDP (Gambar 1). Sebagai pembanding digunakan data pada grup kontrol mengahsilkan kecenderungan yang sama $(P>0,05)$ (Gambar 2). 


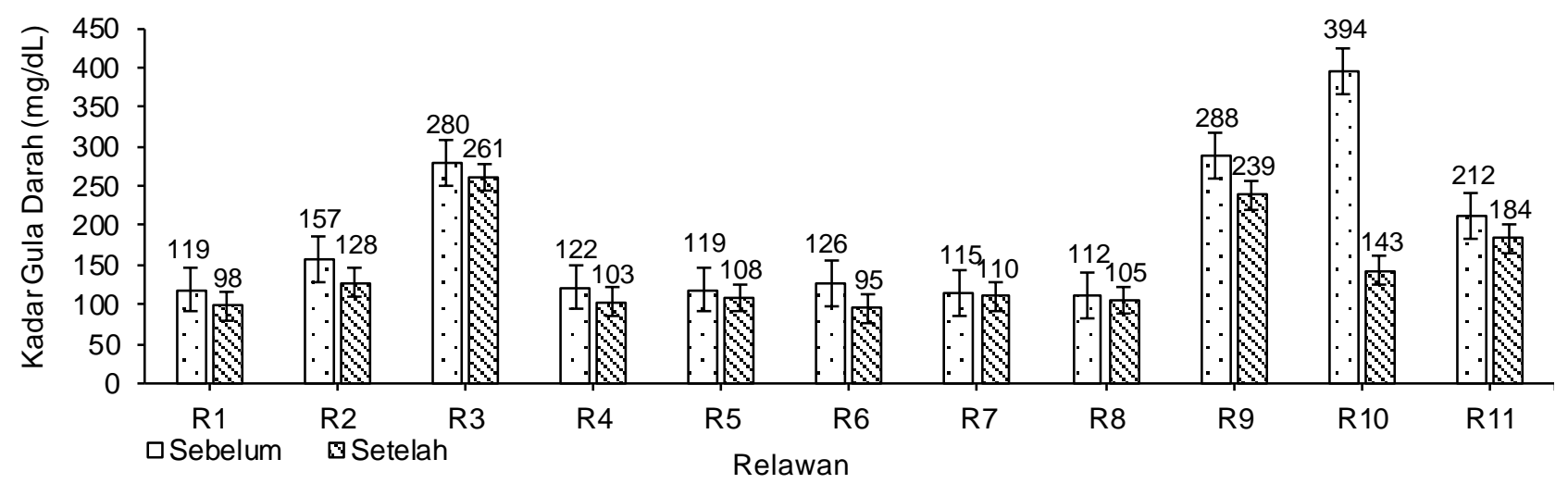

Gambar 1. Nilai kadar glukosa darah puasa $(\mathrm{mg} / \mathrm{dL})$ relawan pada grup yang diitervensi SKH mengandung Mikroenkapsulan MSMn pada hari ke-0 dan hari ke-28

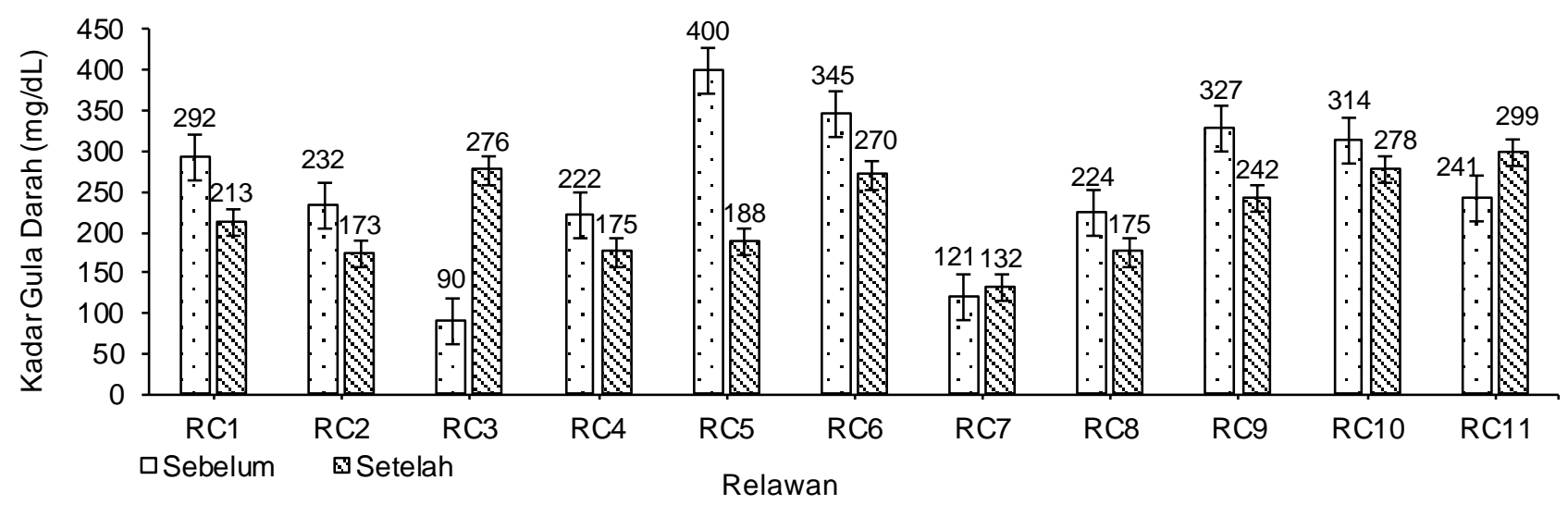

Gambar 2. Nilai kadar glukosa darah puasa $(\mathrm{mg} / \mathrm{dL})$ relawan grup kontrol pada hari ke-0 dan hari ke-28

Minuman SKH merupakan minuman yang memiliki nilai indeks glikemik rendah, serat, selain itu juga memiliki kandungan senyawa bioaktif yang tinggi seperti golongan antioksidan, antosianin, dan isoflavon (Mueller et al., 2012; Martino et al., 2011). Perubahan kadar GDP relawan yang diintervensi diduga karena minuman tersebut memiliki nilai IG yang rendah, serat dan kandungan lainnya yang dapat memberikan energi yang cukup untuk menunda rasa lapar. Produk dengan IG rendah dan serat mampu memberikan rasa kenyang tanpa meningkatkan glukosa dalam darah dan dapat memperbaiki sensitivitas insulin (Riccardi et al., 2008). Serat dapat menurunkan jumlah karbohidrat yang dapat dicerna, selain itu serat juga dapat menurunkan tingkat hormon pencernaan. Serat kedelai mengandung pektin, galaktomanan, dan arabinogalaktan yang memiliki viskositas yang tinggi. Komponen serat ini dapat memperlambat laju pencernaan dan penyerapan glukosa (Verschoyle et al., 2007). Pengaruh dari serat kedelai menjadi penyebab penurunan laju pencernaan yang berakibat pada perlambatan penyerapan glukosa dengan membatasi laju difusi intraluminal glukosa dengan penyerapan permukaan. Produk minuman ataupun makanan yang tinggi serat dapat menunda rasa lapar sehingga memberikan kesempatan bagi hormon insulin dalam tubuh untuk memproses makanan yang tinggi glukosa (Bilous dan Donelly, 2015). Selain serat, komponen senyawa bioaktif juga berperan besar dalam menurunkan dan mengontrol penyakit DM-2. Komponen bioaktif tersebut dapat menurunkan tingkat stres oksidatif dan mencegah terjadinya komplikasi mikro- maupun makro-vaskular pada penderita DM-2 (Franz, 2012).

Berdasarkan hasil penelitian yang dilaporkan oleh Sedaghat et al. (2015), relawan DM-2 yang diberi intervensi kedelai sebanyak $30 \mathrm{~g}$ pada pagi dan sore selama 8 minggu menunjukkan penurunan GDP secara signifikan dari $165,50 \pm 51,00 \mathrm{mg} / \mathrm{dL}$ menjadi $148,20 \pm 49,00 \mathrm{mg} / \mathrm{dL}$. Hasil GDP ini berbeda dengan hasil penelitian dimana nilai GDP relawan yang intervensi produk tidak menunjukkan penurunan signifikan dari 185,82 $\pm 95,50$ menjadi $143,09 \pm 58,93 \mathrm{mg} / \mathrm{dL}$. Hal ini terjadi diduga relawan yang diintervensi dengan produk tidak dikontrol pola diet selama masa intervensinya. Pada relawan kontrol, Sedaghat et al. (2015), melaporkan terjadi peningkatan kadar GDP secara signifikan dari $161,70 \pm 41,20 \mathrm{mg} / \mathrm{dL}$ menjadi $167,50 \pm 42,30 \mathrm{mg} / \mathrm{dL}$ pada grup kontrol. Temuan ini juga berbeda dari temuan pada grup kontrol pada penelitian ini yang secara kontras tidak berbeda signifikan (dari $255,00 \pm 93,33 \mathrm{mg} / \mathrm{dL}$ menjadi $220,00 \pm 55,50 \mathrm{mg} / \mathrm{dL}$ ). 
Lebih lanjut, Chang et al. (2008) melakukan intervensi terhadap relawan dengan memberikan total konsumsi kedelai setara $69 \mathrm{~g}$ yang dibagi dalam 3 kali konsumsi sehari berupa suplemen selama 4 minggu dan hasilnya menunjukkan terjadi penurunan GDP relawan pada grup yang diintervensi secara signifikan dari $169,70 \pm 23,00 \mathrm{mg} / \mathrm{dL}$ menjadi 109,90 $\pm 7,70 \mathrm{mg} / \mathrm{dL}$. Begitupun kadar GDP relawan kontrol menunjukkan penurunan secara signifikan berdasarkan hasil temuan Chang et al. (2008) dari $183,00 \pm 14,70 \mathrm{mg} / \mathrm{dL}$ menjadi $173,00 \pm$ $9,80 \mathrm{mg} / \mathrm{dL}$. Apabila dibandingkan hasil penelitian yang dilakukan dengan hasil temuan sedaghat et al. (2015) dan Chang et al. (2008) terlihat bahwa relawan yang dintervensi dengan produk selama 28 hari tidak mengalami penurunan yang signifikan. Hal ini diduga karena masa intervensi yang lebih pendek, pola diet yang tidak diatur dan jumlah pemberian produk yang perlu untuk ditingkatkan.

\section{Kadar enzim COX-2}

Hiperglikemia berkaitan dengan peningkatan produksi senyawa radikal bebas. Jumlah senyawa radikal bebas tinggi dapat memicu ketidakseimbangan dalam tubuh, yaitu yang dikontrol oleh sistem homeostasis. Inflamasi adalah salah satu kondisi yang dapat menganggu homeostasis tersebut (Bilous dan Donelly, 2015). Reaksi inflamasi merusak sel sehingga meningkatkan kadar enzim COX-2 (Aid dan Bosetti, 2011). Menurut Bagi et al. (2006), COX-2 memegang peran penting dalam biosintesis prostaglandin selama inflamasi yang menyebabkan peningkatan keparahan penyakit DM2. Nilai OD enzim COX-2 yang tinggi menunjukkan tingkat seyawa radikal bebas yang tinggi, sebagai indikasi terjadi inflamasi dalam tubuh. Hasil penelitian yang telah dilakukan terhadap relawan yang diintervensi dengan produk minuman SKH mengandung mikroenkapsulan MSMn menunjukkan penurunan nilai OD COX-2 secara signifikan pada taraf $5 \%$ (Gambar 3) berdasarkan uji $t$-student berpasangan $(P<0,05)$. Penurunan nilai OD COX-2 grup yang diintervensi produk mengindikasikan terjadi penurunan tingkat inflamasi. Hal ini diduga karena kandungan senyawa bioaktif pada SKH yang diujikan seperti $\beta$-karoten, isoflavon dan antosianin dapat meredam proses inflamasi (Messina, 2010; Kim et al., 2013). Begitupun dengan, nilai OD enzim COX-2 pada grup kontrol (Gambar 4) yang juga berbeda signifikan pada taraf $5 \% \quad(P<0,05)$ berdasarkan uji $t$-student berpasangan. Hal tersebut dapat disebabkan karena adanya edukasi pola makan dan hidup sehat serta mungkin waktu intervensi yang perlu diperpanjang untuk melihat hasil yang lebih nyata.

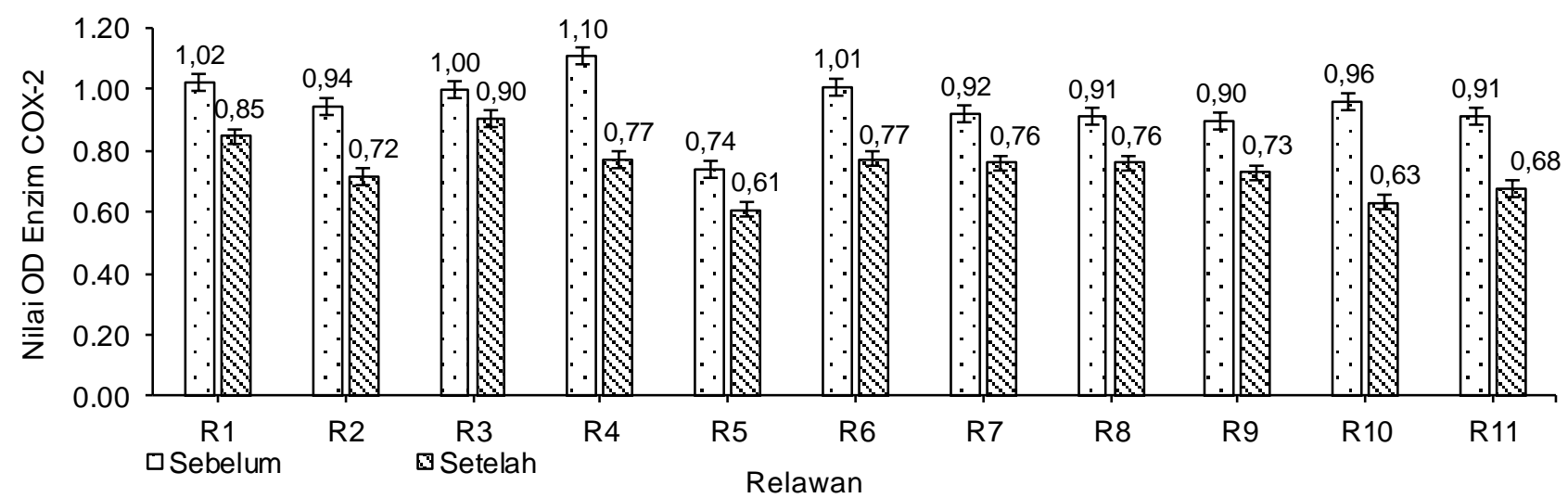

Gambar 3. Nilai OD enzim COX-2 relawan grup intervensi SKH + Mikroenkapsulan MSMn pada hari ke-0

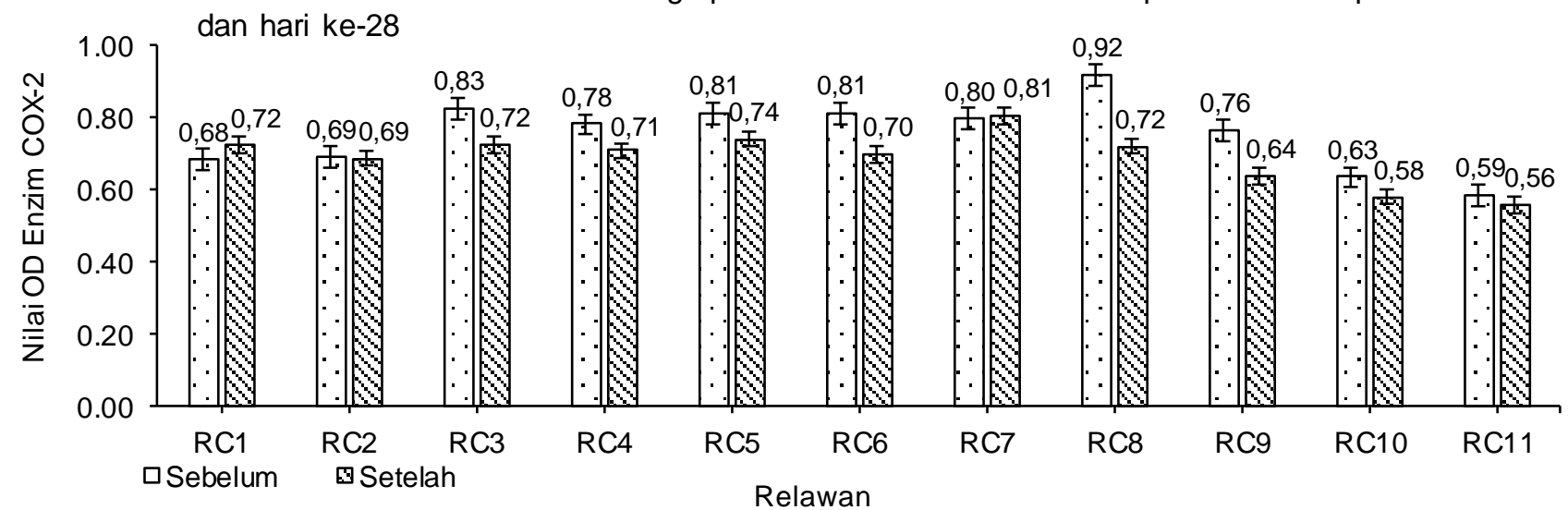

Gambar 4. Nilai OD enzim COX-2 relawan grup kontrol pada hari ke-0 dan hari ke-28 


\section{Kadar malonaldehid (MDA)}

Malonaldehid merupakan senyawa yang sangat toksik sebagai produk yang terbentuk dari oksidasi lipid dan dapat juga dari prostaglandin dan sintesis tromboksan (Winarsi, 2007). Beberapa penelitian menunjukkan bahwa konsentrasi MDA tinggi berhubungan dengan tingkat keparahan DM-2 (Bose dan Agrawal, 2007). Relawan DM-2 cenderung memiliki senyawa radikal bebas yang tinggi dalam tubuh. Hasil penelitian yang menunjukkan penurunan nilai MDA relawan mengindikasikan ada perbaikan akibat intervensi perlakuan dengan penurunan senyawa radikal. Berdasarkan hasil penelitian yang telah dilakukan, kadar MDA relawan DM-2 yang diintervensi dengan produk SKH mengandung mikroenkapsulan MSMn (Gambar 5) mengalami penurunan signifikan pada taraf nyata $5 \% \quad(P<0,05)$ berdasarkan uji $t$-student berpasangan dari $5,19 \pm$ $0,59 \mathrm{nmol} / \mathrm{mL}$ menjadi $4,47 \pm 0,71 \mathrm{nmol} / \mathrm{mL}$. Sebaliknya, hasil pengujian kadar MDA grup kontrol (Gambar 6) tidak berbeda signifikan $(P>0,05)$ dari $4,81 \pm 0,69 \mathrm{nmol} / \mathrm{mL}$ menjadi $5,18 \pm 0,83 \mathrm{nmol} / \mathrm{mL}$. Penurunan kadar MDA pada grup yang diintervensi produk diduga atas kontribusi senyawa bioaktif dalam produk baik berupa enzim, vitamin, dan senyawa lain yang dimiliki oleh produk tersebut misalnya $\beta$-karoten, antosianin, dan isoflavon (Winarsi, 2007).

Hasil penelitian ini mendukung hipotesis bahwa produk minuman SKH yang mengandung mikroenkapsulan MSMn dapat menurunkan kadar MDA. Astuti et al. (2009) melaporkan penurunan yang signifikan terhadap kadar MDA tikus yang diintervensi selama 2 bulan dengan isoflavon dan tepung kedelai. Eszy et al. (2014) juga melaporkan hal yang sama yaitu penurunan signifikan kadar MDA pada tikus yang diintevensi dengan pemberian diet tinggi $\mathrm{MSMn}$ dari $2,49 \pm 0,50 \mathrm{nmol} / \mathrm{mL}$ menjadi $3,15 \pm 0,24 \mathrm{nmol} / \mathrm{mL}$. Chang et al. (2008), melaporkan perbedaan yang tidak signifikan pada kadar MDA relawan yang diintervensi dengan suplemen kedelai $26,04 \pm 7,60 \mathrm{nmol} / \mathrm{mL}$ dengan kelompok kontrol $27,20 \pm 3,60 \mathrm{nmol} / \mathrm{mL}$. Adanya perbedaan hasil intervensi terhadap kadar MDA dapat disebabkan oleh beberapa faktor antara lain lamanya masa intervensi dan bentuk bahan intervensi.

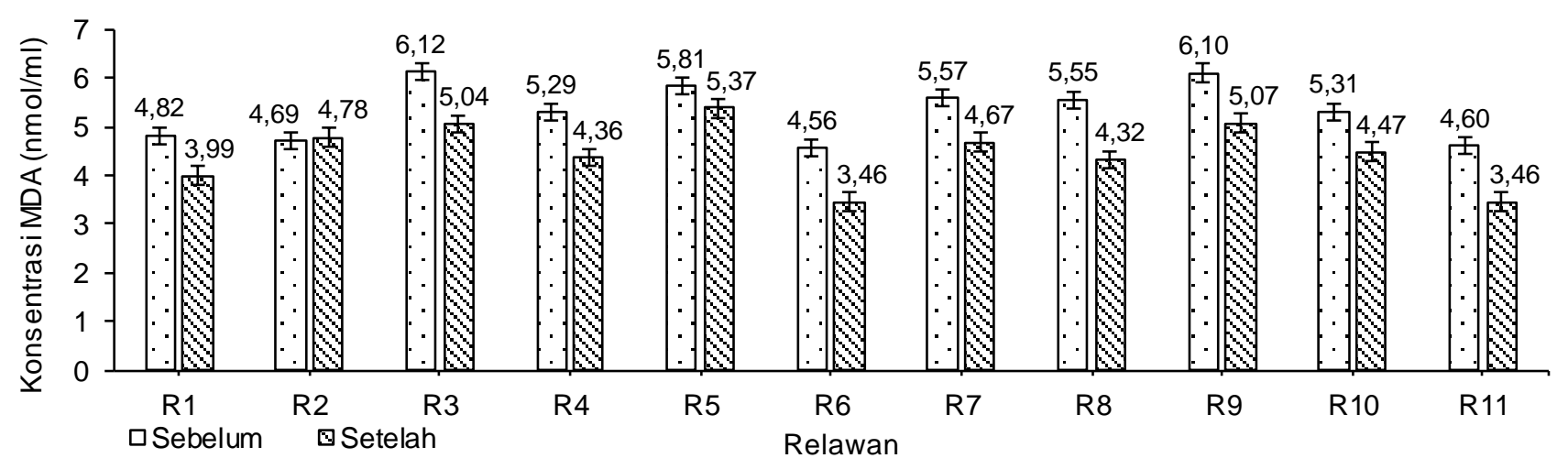

Gambar 5. Nilai konsentrasi MDA relawan grup intervensi SKH mengandung Mikroenkapsulan MSMn pada hari ke-0 dan hari ke-28

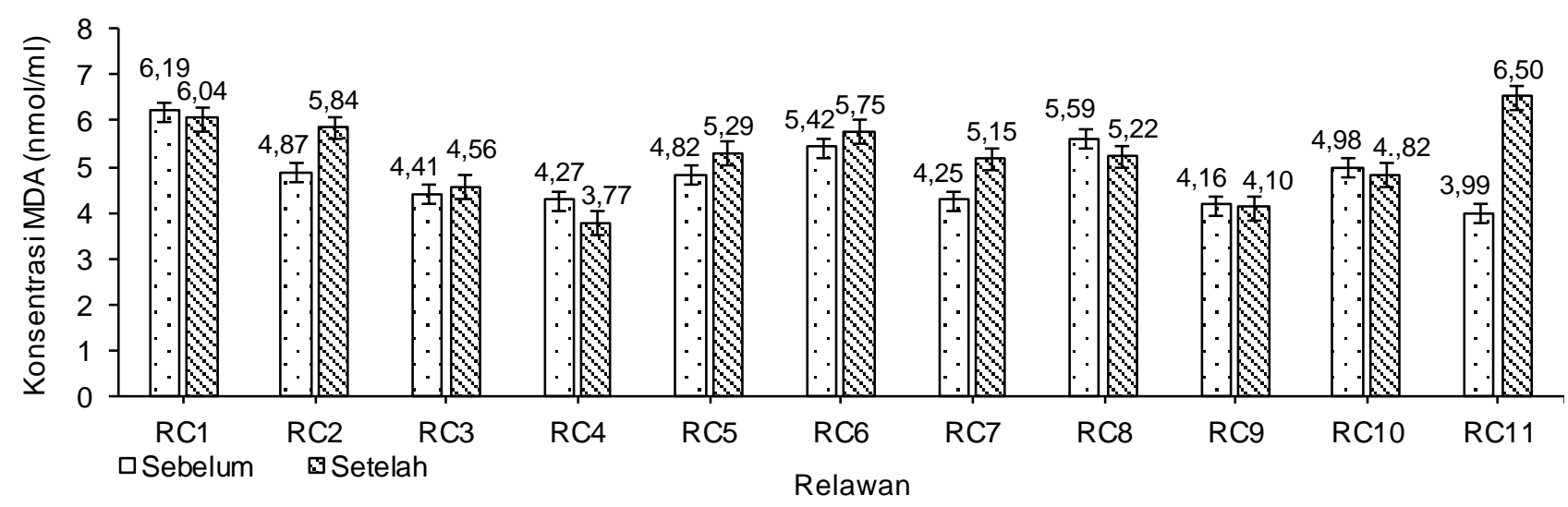

Gambar 6. Nilai konsentrasi MDA relawan pada grup kontrol pada hari ke-0 dan hari ke-28 


\section{KESIMPULAN}

Mikroenkapsulan MSMn memiliki kadar air $1,77 \pm 0,15 \%$, kelarutan $65,39 \pm 2,71 \%$ dan total karoten 295,24 $\pm 7,40$ ppm. Minuman SKH mengandung mikroenkapsulan MSMn memiliki peran fungsional dalam mengendalikan dan memperbaiki kondisi penyakit DM-2 secara nyata berdasarkan uji statistik $t$-student berpasangan pada taraf nyata $5 \%$ berdasarkan hasil analisis parameter kadar malonaldehida, dan kadar siklooksigenase. Namun perlu dilakukan pengujian dari masa intervensi yang lebih panjang untuk melihat pengaruh yang lebih nyata pada produk yang sama, dan peningkatan jumlah produk yang diintervensi, serta diperlukan pengontrolan diet relawan.

\section{UCAPAN TERIMA KASIH}

Penulis mengucapkan terima kasih atas dana bantuan pendidikan BPPDN dari DIKTI tahun 2013 dan dukungan dana penelitian dari IPB dan PT. Kreasi Inovasi Prosana atas nama Prof.Dr.Ir. Fransiska Rungkat Zakaria, M.Sc.

\section{DAFTAR PUSTAKA}

[ADA] American Diabetes Association. 2010. Diagnosis and classification of diabetes mellitus. Diabetes Care 33: S62-S69. DOI: 10.2337/dc10-S062.

Ahn JH, Kim YP, Seo EM, Choi YK, Kim HS. 2008. Antioxidant effect of natural plant extracts on the microencapsulated high oleic sunflower oil. J Food Eng 84: 327-334. DOI: 10.1016/j.jfood eng.2007.05.029.

Aid S, Bosetti F. 2011. Targeting cyclooxygenases-1 and -2 in neuroinflammation: therapeutic implications. Biochimie 93: 46-51. DOI: 10.1016/j.biochi.2010.09.009.

Astuti S, Muchtadi D, Astawan M, Purwantara B, Wresdiyati T. 2009. Pengaruh pemberian tepung kedelai kaya isoflavon terhadap kadar malonaldehid (MDA), aktivitas superoksida dismutase (SOD) testis dan profil $\mathrm{Cu}, \mathrm{Zn}-\mathrm{SOD}$ tubuli seminiferi testis tikus jantan. $\mathrm{J}$ Teknol Industri Pangan 20: 129-134.

[AOAC] Association of Official Analytical Chemists. 2005. Official method of analysis. 16th Edition. Chapter 12, 2-41. Microchemical Methods. Association of Official Analytical Chemistry International, Gaithersburg.

Bagi Z, Erdei N, Papp Z, Edes I, Koller A. 2006. Upregulation of vascular cyclooxygenase-2 in diabetes mellitus. Pharmacological Reports Pharmacological Rep 58: 52-56.
Biglari F, Alkarkhi AFM, Easa AM. 2008. Antioxidant activity and phenolic content of various date palm (Phoenix dactylifera) fruits from Iran. Food Chem 107: 1636-1641. DOI: 10.1016/ j.foodchem.2007.10.033.

Bilous R, Donelly R. 2015. Buku Pegangan Diabetes. Yudha EK, penerjemah; Bariid NB, editor. Jakarta (ID): Ed ke-4. 46-65. Penerbit Bumi Mustika. Terjemahan dari: Handbook of Diabetes.

Boateng CO, Lee KT. 2013. Sustainable utilization of oil palm wastes for bioactive phytochemicals for the benefit of the oil palm and nutraceutical industries. Phytochem Rev 12: 173-190. DOI: 10.1007/s11101-013-9270-z.

Bose KSC, Agrawal BK. 2007. Effect of short term supplementation of tomatoes on antioxidant enzymes and lipid peroxidation in type-ll diabetes. Indian J Clin Biochem 22: 95-98. DOI: 10.1007/BF02912889.

[BSN] Badan Standarisasi Nasional. 1999. SNI Sari Bubuk (SNI 01-2970-1999). Jakarta.

[BSN] Badan Standarisasi Nasional. 1995. SNI Sari Kedelai (SNI 01-2983-1995). Jakarta.

[BSN] Badan Standarisasi Nasional. 1992. SNI Kopi Instan (SNI 01-2983-1995). Jakarta.

Chang JH, Kim MS, Kim TW, Lee SS. 2008. Effects of soybean supplementation on blood glucose, plasma lipid levels, and erythrocyte antioxidant enzyme activity in type-2 diabetes mellitus patients. Nutr Res Practice 2: 152-157. DOI: 10.4162/nrp.2008.2.3.152.

Chen L, Bai G, Yang R, Zang J, Zhou T, Zhao G. 2014. Encapsulation of b-carotene within ferritin nanocages greatly increases its water-solubility and thermal stability. Food Chem 149: 307-312. DOI: 10.1016/j.foodchem.2013.10.115.

Dubey R, Shami TC, Rao KUB. 2009. Microencapsulation technologi and aplications. Defence Sci J 59: 82-95.

Eszy MS, Sastri S, Masri M. 2014. Pengaruh pemberian diet tinggi minyak sawit terhadap kadar malondialdehid darah tikus wistar. J Kesehatan Andalas 3: 409-414.

Franz MJ. 2012. Medical Nutrition Theraphy for Diabetes Mellitus and Hypoglycemia of Nondiabetic Origin. In: Mahan LK, Stump SE, Editors. Krause's Food and the Nutrition Care Process 13th Edition. Philadelphia: WB Saunders Company. 675-710.

[IDF] International Diabetes Federation. 2013. IDF Diabetes atlas. Sixth edition. http://www.idf.org /diabetesatlas [20 Oktober 2014].

Kim K, Lim KM, Shin HJ, Seo DB, Noh YJ, Kang S, Chung HY, Shin S, Chung JH, Bae ON. 2013. 
Inhibitory effects of black soybean on platelet activation mediated through its active component of adenosine. Thrombosis Res 131: 254-261. DOI 10.1016/j.thromres.2013.01.002.

Kim SL, Berhow MA, Kim JT, Chi HY, Lee SJ, Chung IM. 2006. Evaluation of soyasaponin, isoflavone, protein, lipid, and free sugar accumulation in developing soybean seeds. $J$ Agr Food Chem 54: 10003-10010. DOI: 10.10 21/jf062275p.

Lameshow S, Hosmer J, Klar J, Lwanga SK. 1997. Besar Sampel dalam Penelitian Kesehatan. Yogyakarta. 46-55. Gajah Mada University Press.

Martino HSD, Cardoso LM, Ribeiro SMR, Dantas MIS, Piovesan ND, Mejia ED. 2011. Nutritional and Bioactive Compounds of Soybean: Benefits on Human Health. Chapter 21. 465-489. InTech. Rijeka, Croatia. DOI: 10.5772/17575.

Messina M. 2010. Soybean isoflavone exposure does not have feminizing effects on men: a critical examination of the clinical evidence. Fertil Steril 93: 2095-2104. DOI: 10.1016/j. fertnstert.2010.03.002.

Mueller NT, Odegaard AO, Gross MD, Koh WP, Yu MC, Yuan JM, Pereira MA. 2012. Soy intake and risk of type-2 diabetes mellitus in Chinese Singaporeans. Eur J Nutr 51: 1033-1040. DOI: 10.1007/s00394-011-0276-2.

[PORIM] Palm Oil Research Institute of Malaysia. 2005. Test Methods for Palm Oil and Palm Oil Products. Kuala Lumpur, Malaysia.

Powell KF, Holt SHA, Miller JCB. 2002. International table of glycemic index and glycemic load values. Am J Clin Nurt 76: 5-56.

Rahman H. 2015. Peningkatan Skala Produksi Mikroenkapsulan Minyak Sawit Merah dan Aplikasinya pada Beberapa Produk Pangan [Skripsi]. Bogor: Fakultas Teknologi pertanian, Institut Pertanian Bogor.

Riccardi G, Rivellese AA, Giacco R. 2008. Role of glycemic index and glycemic load in the healthy state, in prediabetes, and in diabetes. Am J Clin Nurt 87: 269S-274S.
Sedaghat A, Shahbazian H, Haidari F, Payami SP, Jahanshahi A, Latifi SM. 2015. The effect of soy nuts on glycemic control, lipid profile and insulin-resistance in type-2 diabetic patients. J Endocrine Met Disease 5: 1-7. DOI: 10.4236/ ojemd.2015.51001.

Singh RP, Murthy, KNC, Jayaprakasha. 2002. Studies on antioxidant activity of pomegranate (Punica granatum) peel and seed extracts using in vitro models. J Agr Food Chem 50: 81-86.

Slavin M, Lu Y, Kaplan N, Yu L. 2013. Effects of baking on cyanidin-3-glucoside content and antioxidant properties of black and yellow soybean crackers. Food Chem 141: 1166-1174. DOI: 10.1016/j.foodchem.2013.04.039.

Umesha SS, Monahar B, Naidu KA. 2013. Microencapsulation of a-linolenic acid-rich garden cress seed oil: physical characteristics and oxidative stability. Eur J Lipid Sci Tech 115: 1475-1482. DOI: 10.1002/ejlt.201300181.

Verschoyle RD, Greaves P, Cai H, Edwards RE, Steward WP, Gescher AJ. 2007. Evaluation of the cancer chemopreventive efficacy of rice bran in genetic mouse models of breast, prostate and intestinal carcinogenesis. Brit $\mathrm{J}$ Cancer 96: 248-254. DOI: 10.1038/sj.bjc. 6603539.

Winarsi H. 2007. Antioksidan Alami dan Radikal Bebas. Ed ke-2, 26-50. Kanisnus Yogyakarta: Kanisius.

Wulandari N, Adawiyah DR, Pramuhadi G. 2014. Drying process of microencapsulated red palm oil. Seafast Center. https://seafast.ipb.ac.id/ publication/presentation/fpr-01.2-nur-wulandari. pdf. [18 Oktober 2016].

Wulandari N, Muchtadi TR, Irene R. 2015. Palm oil microencapsulation by coacervation, thin layer drying, and silica dioxide absorption technique. World J Eng Technol 3: 26-30. DOI: 10.4236/ wjet.2015.33B005.

Zakaria FR, Azni IN, Syamsir E, Amalia KM, Yamani C. 2014. Pengaruh konsumsi minuman beroksigen terhadap inflamsi dan kapasitas antioksidan penderita paru obstruktif kronik (PPOK). J Teknol Industri Pangan 25: 31-38. DOI: 10.6066/jtip.2014.25.1.31. 